\title{
INTRODUCTION
}

\section{The necissaty of Blanching:}

Prior to freezing preservation vegetables are custemairly blanched in hot water or steam as an essential method for enzyme inactivation and to maintain higher quality (Monzini et al, 1999). Frozen storage and blanching arereducing the numbers of microorganisms (Michell 1999). Odland and Eheart (1998) studied the effect of different blanching methods on the physical properties of some vegetables They found that the water blanching lower the total solids than steam blanched either with or without any additions, the losses of ascorbic acid increased with increasing blanching time and ash content. Decrased as well as potassium. The loss of nutrients occures mainly due to osmosis. (Gasilve et al., 2001). An amount of total chlorophyll is lost during blanching converted to pheophytin ; the conversion being proportional to the degree of heat treatment applied during blanching. (Katsaboxakis, 2000).

Many vegetables with home blanching; about $10 \%$ of vitamin ${ }^{\circ}(\mathrm{c})$ content is lost; and about $75 \%$ of vitamic "c" lost during the first 3 months of frozen storage and almost completely loss after 6 months. Katsaboxakis, 2000 The loss of total sugar as well as the majority of minerals increased by the time of blanching increament and / or the frozen storage period (Halpin and Lee 2002).

Pheophytin did not change during storage for 6 months at $-15^{\circ} \mathrm{c}$ but there was a significant loss of chlorophyll (b), (Odland and Eheart, 1998). 
A study on the Nutrient status and sensory evaluation of some vegetables "frozen \& storage at home"

Effect of blanching, freezing and frozen storage on the sensory parameters :

Softening is a major change brought about by heating vegetables, the softening is accompanied by a solubilization and depolymerization of pectin.

During blanching large amounts of water are imbibed by the gelatinized granules.

Texture measured by mouthfeel as an important parameter of quality attributes of foods. In general slow freezing causes large ice crystals and cell membrane rupture which allows cell sap to leach out during thawing. Fast freezing produces small ice crystals that do not rupture cell membrane and the result is a firm texture product (Hiak, 1998).

During frozen storage, recrestalization causes ice crystals to grow at the expense of smaller ones. This recrystalization also is a function of storage time and temprature. Fast freezing produces small ice crystals that do not rucpture the cell membranes during freezing (Hiak, 1998).

Chewiness of frozen peas increased with storage time. Sensory tenderness decreased early in storage and then incresed (Lion, 1998).

\section{Aim of the Study :}

1- To help the housekeeper to know the preferable and appropriate home blanching time of pease, okra and carrots that keep the top quality of the frozen vegetables.

2- To follow changes in nutrient content and in the sensory evaluation of the frozen vegetables that occure after the home blanching time and frozen storage for 3 months 
at $-20^{\circ} \mathrm{c} \pm 2^{\circ} \mathrm{c}$.

3- To identifi the housekeeper by the physical changes of the frozen storage that might occure during blanching and storage period for 3 months at $-20^{\circ} \mathrm{c} \pm 2^{\circ} \mathrm{c}$.

\section{The Methedology:}

We chosed 3 kinds of green vegetables peas, okra and carrots which were harvested at the top of their season. Every vegetable was chosed from one type. green peas seeds were separated. The stem caps of okra were cut off and discarded. The carrots were sliced.

The blanching process was carried out at $90^{\circ} \mathrm{c}$ for 2 , 3 and 5 minutes by using the tap water. Each kind was separately cooled in cool water then drained and packed $(200 \mathrm{gm} / \mathrm{bag})$. Then they were stored at $-20^{\circ} \mathrm{c} \pm 2^{\circ} \mathrm{c}$ for 3 months. The nutrients were analyzed in the fresh samples and in every branch before and after the frozen storage period ( 3 months) and in every blanching water treatment time (2, 3 and 5 minutes). The organoleptic parameters were evaluated as well as the panel test for every vegetable.

\section{Chemical Analysis :}

(1) Determination of moisture and ascorbic acid : Accroding to $A . O . A . C$., (1985).

(2) Determination of total carotenoids : as the method that described by Wetlestein, (1957).

(3) Determination of total sugar : According to the methods described by Jacob, (1958) and smogyi, (1945).

(4) Determination of minerals : Calcium and iron were determined by using PU unica -msp 19300 atomic absorption spectrophotometr. Phosphorous content was measured colorimetrically. Sodium and potassium were 
determined by using flam photometer (Jen way, model PFPV, NO, 8846,A.R. C ). The concentration of the tested element was determined via a standard curve of sodium chloride and potassium chloride (Jacob , 1958).

(6) Sensory Evaluation: The sensory evaluation was carried out on the samples by using colomn and by the panelists for the vegetables samples before and after the frozen storage period ( 3 months) and after cooking. Texture determined by using amatek universal testing machine model AIM 3339-3 (Largo, Florida 33543, USA) equipped wit AIM desktop micro-Computer (A65-500 series). Color (Chroma-hue) measured by using a hunter lab model D-25 color \& color difference meter according to Wongana, 1987 method.

\section{Results and Discussion}

\section{(1) Moisture content :}

'Table (1-a): Effect of blanching treatment times, and frozen storage period on moisture content as percentage of fresh weight in green peas.

\begin{tabular}{|c|c|c|c|c|c|c|}
\hline \multirow{3}{*}{$\begin{array}{l}\text { Blanching } \\
\text { treatment time }\end{array}$} & \multicolumn{3}{|c|}{ After blanching } & \multicolumn{3}{|c|}{$\begin{array}{c}\text { Storage period after } 3 \\
\text { months } \\
\left(-20^{\circ} \mathrm{c} \pm 2^{\circ} \mathrm{c}\right)\end{array}$} \\
\hline & \multirow{2}{*}{$\begin{array}{l}\text { Zero } \\
\text { time }\end{array}$} & \multicolumn{2}{|c|}{ Change } & \multirow{2}{*}{$\begin{array}{c}\text { Weight } \\
\text { (mg.) }\end{array}$} & \multicolumn{2}{|c|}{ Change } \\
\hline & & (mg.) & $\%$ & & (mg.) & $\%$ \\
\hline 2 minutes. & 81.42 & +2.45 & +3.10 & 78.16 & -0.81 & -1.02 \\
\hline 3 minutes & 81.85 & 2.88 & +3.65 & 78.00 & -0.97 & -1.23 \\
\hline 5 minutes & 82.16 & 3.19 & +4.52 & 77.58 & -1.39 & -1.76 \\
\hline
\end{tabular}

Moisture in the fresh sample $=78.97 \%$

Table (1-a) represents the effect of blanching treatment times and frozen storage on moisture content as percentage of the fresh weight in green peas. It is clear that the moisture content was increased by the time increament. 
It increased (3.1\% of the fresh sample) when blanching time is 2 minutes and decreased after the frozen storage period by $-1.02,-1.23$ and $-1.76 \%$ of the fresh sample when the blanching times are 2,3 and 5 minutes respectively. This increament may be due to the loss of solid during blanching (Polo 1999). Our results are agreed well with those of shibairo et al., 2001; they frozed green beans using different blanching treatments. They found that the loss of total solids during water blanching was significantly lower than that of steam blanching.

Table (1-b) represents the effect of blanching treatment times and frozen storage on moisture content as percentage of fresh weight in Okra. It is clear that the increaament in weight increased by the time exceeding the increaament after the blanching treatment ranged from $1.8 \%$ to $3.9 \%$ of the fresh weight. Blanching for 2 minutes scores the least increament because the condensation of water on the surface of blanched vegetables followed by drainning off (Pollo 1999) frozen storage for 3 months at $-20^{\circ} \mathrm{c} \pm 2^{\circ} \mathrm{c}$ ; blanching for 5 minutes scores $-0.09 \mathrm{gm}$. It was the least decreament. Our results agreed well with those of Shibairo et al ., (2001) when they blanched okra by steam for 2 and 4 minutes; they found that the increase was 1.08 and $5.37 \%$ of the fresh sample respectively and when they stored (frozen okra at $-20^{\circ} \mathrm{c}$ for 3 months; they found that the decreament was 0.19 and $1.65 \%$ of the fresh sample for 2 and 4 minutes respectively Pollo (1999); explained this by the instability of storage temprature. 
A study on the Nutrient status and sensory evaluation of some vegetables "frozen \& storage at home"

Table (1-b): Effect of blanching treatment times, and frozen storage period on moisture content as percentage of fresh weight in okra.

\begin{tabular}{|c|c|c|c|c|c|c|}
\hline \multirow{3}{*}{$\begin{array}{c}\text { Blanching } \\
\text { treatment } \\
\text { time }\end{array}$} & \multicolumn{3}{|c|}{ After blanching } & \multicolumn{3}{|c|}{$\begin{array}{l}\text { Storage period after } 3 \text { months } \\
\left(20^{\circ} \mathrm{c} \pm 2^{\circ} \mathrm{c}\right)\end{array}$} \\
\hline & \multirow{2}{*}{$\begin{array}{l}\text { Zero } \\
\text { time }\end{array}$} & \multicolumn{2}{|c|}{ Change } & \multirow{2}{*}{$\begin{array}{c}\text { Weight } \\
\text { (mg.) }\end{array}$} & \multicolumn{2}{|c|}{ Change loss } \\
\hline & & (mg.) & $\%$ & & (mg.) & $\%$ \\
\hline 2 minutes. & 86.16 & 1.52 & +1.80 & 86.07 & -0.09 & -0.11 \\
\hline 3 minutes & 87.19 & 2.56 & +3.03 & 86.66 & -0.53 & -0.63 \\
\hline 5 minutes & 87.93 & 3.30 & +3.90 & 87.85 & -0.08 & -0.09 \\
\hline
\end{tabular}

Moisture in the fresh sample $=84.63 \%$

The results of the effect of blanching treatment times and frozen storage on moisture content in carrots as percentage of the fresh weight are represented in table (1-c). It is clear that, moisture content was increased with increasing blanching time. Moisture increased by (1.79, 1.98 and $2.5 \%$ ) of the fresh sample for 2,3 and5 minutes respectively.

The change in moisture content after the storage period ( 3 months) at $-20^{\circ} \mathrm{c}$ decreased slightly $(0.2$ and $0.23 \%$ ) of the fresh weight for 2 and 3 minutes respectively. The decrease was twiced $(-0.45) \%$ of the fresh sample for 5 minutes blanching time. (Polo, 1999) found that the dry matter of carrots was greatly reduced stepwise blanching $70^{\circ} \mathrm{c}$ for 15 minutes followed by 2 minutes at $100^{\circ} \mathrm{c}$. They explained the increament due to the conversion of starch to gel. 
A study on the Nutrient status and sensory evaluation of some vegetables "frozen \& storage at home"

Table (1 - C ) : Effect of blanching treatment and frozen storage on moisture content in carrots as percentage of the fresh weight

\begin{tabular}{|c|c|c|c|c|c|c|}
\hline \multirow{3}{*}{$\begin{array}{c}\text { Blanching } \\
\text { treatment time }\end{array}$} & \multicolumn{3}{|c|}{ After blanching } & \multicolumn{3}{|c|}{$\begin{array}{c}\text { Storage period after } 3 \\
\text { months }\left(-20^{\circ} \mathrm{c} \pm 2^{\circ} \mathrm{c}\right)\end{array}$} \\
\hline & \multirow{2}{*}{$\begin{array}{l}\text { Zero } \\
\text { time }\end{array}$} & \multicolumn{2}{|c|}{ Change } & \multirow{2}{*}{$\begin{array}{l}\text { Weight } \\
\text { (mg.) }\end{array}$} & \multicolumn{2}{|c|}{ Change } \\
\hline & & (mg.) & $\%$ & & (mg.) & $\%$ \\
\hline 2 minutes. & 90.79 & +1.60 & 1.79 & 89.01 & -0.18 & 0.20 \\
\hline 3 minutes & 90.96 & +1.77 & 1.98 & 88.96 & -0.23 & 0.26 \\
\hline 5 minutes & 91.50 & +2.31 & 2.59 & 88.79 & -0.40 & 0.45 \\
\hline
\end{tabular}

Moisture in fresh sample $=89.19 \mathrm{mg} / 100 \mathrm{~g}$.

\section{(2) Vitamin " $C$ " content :}

Ascorbic acid is a sensitive vitamin. It is usually unstable to alkali, oxygen, light and heat but stable in acid media (Harris , 1998). Our results of all studied samples indicated a reduction in vitamin $\mathrm{C}$ content.

Harris, (1998) referred that; home blanching caused a loss about $10 \%$ from vitamin (c) content and the loss was $75 \%$ during the first three months of frozen storage and almost completely loss after six months.

Table (2-a) shows the effect of blanching treatment times and frozen storage on ascorbic acid content as percentage of fresh weight in green pease; the loss of vitamin (c) ranged from 18.5 to $28.22 \%$ of the fresh sample. The loss of vitamin " $c$ " is increased by the time increament. After three months (the frozen storage period) vitamin (c) scored the highest loss (28.96\% of the fresh sample ) for 5 minutes blanching time. Our results are agreed well with those of Halpin and Lee (2002); they found that the loss of ascorbic acid during water blanching increased significantly with time increasing ( 3 to 6 minutes). 
A study on the Nutrient status and sensory evaluation of some vegetables "frozen \& storage at home"

Table (2-a): Effect of blanching treatment times, and frozen storage period on ascorbic acid content as percentage of fresh weight in green peas.

\begin{tabular}{|c|c|c|c|c|c|c|}
\hline \multirow{3}{*}{$\begin{array}{c}\text { Blanching } \\
\text { treatment time }\end{array}$} & \multicolumn{3}{|c|}{ After blanching } & \multicolumn{3}{|c|}{$\begin{array}{l}\text { Storage period after } 3 \\
\text { months }\left(-20^{\circ} c \pm 2^{\circ} \mathrm{c}\right)\end{array}$} \\
\hline & \multirow{2}{*}{$\begin{array}{l}\text { Zero } \\
\text { time }\end{array}$} & \multicolumn{2}{|c|}{ Loss } & \multirow{2}{*}{$\begin{array}{l}\text { Weight } \\
\text { (mg.) }\end{array}$} & \multicolumn{2}{|c|}{ Loss } \\
\hline & & (mg.) & $\%$ & & (mg.) & $\%$ \\
\hline 2 minutes & 61.46 & 13.95 & -18.50 & 55.95 & 19.46 & 25.81 \\
\hline 3 minutes & 58.83 & 16.58 & -21.98 & 55.43 & 19.98 & 26.50 \\
\hline 5 minutes & 54.13 & 21.28 & 28.22 & 53.57 & 21.84 & 28.96 \\
\hline
\end{tabular}

Ascorbic acid in the fresh sample $=75.4 / \mathrm{mg} 100 \mathrm{gm}$.

Table (2-b) indicates the effect of blanching treatment times and frozen storage on ascorbic acid content as percentage of the fresh weight in okra. It showes that the less loss in vitamin (c) was $17.01 \%$ when the blanching time treatment was 2 minutes; while after the storage period (at $\left.20^{\circ} \mathrm{c}\right)$; the loss may be equaled for 3 and5 minutes $(15.01$ and $15.06 \%$ of the fresth sample) respectively.

Table (2-b): Effect of blanching treatment times, and frozen storage period on ascorbic acid content as percentage of fresh weight in okra.

\begin{tabular}{|c|c|c|c|c|c|c|}
\hline \multirow{3}{*}{$\begin{array}{l}\text { Blanching } \\
\text { treatment time }\end{array}$} & \multicolumn{3}{|c|}{ After blanching } & \multicolumn{3}{|c|}{$\begin{array}{l}\text { Storage period after } 3 \text { month } \\
\left(-20^{\circ} \mathrm{c} \pm 2^{\circ} \mathrm{c}\right)\end{array}$} \\
\hline & \multirow{2}{*}{$\begin{array}{l}\text { Zero } \\
\text { time }\end{array}$} & \multicolumn{2}{|c|}{ Change } & \multirow{2}{*}{$\begin{array}{l}\text { Weight } \\
\text { (mg.) }\end{array}$} & \multicolumn{2}{|c|}{ Change } \\
\hline & & (mg.) & $\%$ & & (mg.) & $\%$ \\
\hline 2 minutes. & 23.28 & 4.77 & -17.01 & 20.29 & -2.99 & -10.65 \\
\hline 3 minutes & 17.67 & 10.38 & 36.99 & 13.46 & -4.21 & -15.01 \\
\hline 5 minutes & 12.90 & 15.15 & -54.02 & 8.67 & -4.23 & 15.06 \\
\hline
\end{tabular}

Ascorbic acid in the fresh sample $=28.05 \mathrm{mg} 100 \%$.

The effect of blanching treatment times and frozen storage period on ascorbic acid content in carrots are represented in table (2-c). It is clear that, the lowest loss in vitamin (c) was $20.5 \%$ of the fresh sample for 2 minuets, and the highest loss was occurred for 5 minutes as blanching time treatment which may be still constant after the storage period $(42.88 \%)$ of the fresh sample . 
Our results are similar to those of Elkner et al., (1998). They freezed carrots and pease that treated by amounum bicarbonate and water $\left(90^{\circ} \mathrm{c}\right)$ for 5 minutes and stored for 9 months at $-20^{\circ} \mathrm{c}$. They found that, ascorbic acid content during the frozen storage period was remained constant in the first three months.

Table (2-C) : Effect of blanching treatment times, and frozen storage period on ascorbic acid content in carrots.

\begin{tabular}{|c|c|c|c|c|c|c|}
\hline \multirow{3}{*}{$\begin{array}{l}\text { Blanching } \\
\text { treatment time }\end{array}$} & \multicolumn{3}{|c|}{ After blanching } & \multicolumn{3}{|c|}{$\begin{array}{c}\text { Storage period after } 3 \\
\text { months }\left(-20^{\circ} \mathrm{c} \pm 2^{\circ} \mathrm{c}\right)\end{array}$} \\
\hline & \multirow{2}{*}{$\begin{array}{l}\text { Zero } \\
\text { time }\end{array}$} & \multicolumn{2}{|c|}{ Change loss } & \multirow{2}{*}{$\begin{array}{l}\text { Weight } \\
\text { (mg.) }\end{array}$} & \multicolumn{2}{|c|}{ Change loss } \\
\hline & & (mg.) & $\%$ & & (mg.) & $\%$ \\
\hline 2 minutes. & 42.24 & -10.89 & 20.5 & 41.06 & -12.07 & 22.71 \\
\hline 3 minutes & 34.68 & -18.45 & 34.73 & 40.29 & 12.84 & 36.55 \\
\hline 5 minutes & 30.82 & -22.31 & 42.0 & 20.07 & 15.06 & 42.88 \\
\hline
\end{tabular}

Ascorbic acid in the fresh sample $=53.13 \mathrm{mg} / \mathrm{loog}$

\section{(3) Carotenoids content :}

Table (3-a) shows; the effect of blanching treatment times and frozen storage on carotenoids content as percentage of the fresh weight in green peas. It refers that the carotenoids content in green peas decreased by $(-5.01 \%$ of fresh sample) for 2 minutes, then increased to be $12.32 \%$ for 3 minutes. For 5 minutes as blanching time treatment carotenoids content decreased up to $18.9 \%$ of the fresh sample. After the storage period, the change in carotenoids are less than $1 \%(0.33$ and $0.77 \%$ of the fresh sample) for 2 and 3 minutes respectively. Our results are agreed well with those of Elkner et al (1998) (They found that the carotenoids content decreased significantly $(4.95 \%, 12.37 \%$ and $9.05 \%$ ) for 2,3 and 5 minutes respectively at $\mathrm{p} \leq 0.05$. 
A study on the Nutrient status and sensory evaluation of some vegetables "frozen \& storage at home"

Table (3-a): Effect of blanching treatment times, and frozen storage period on carotenoids content as percentage of fresh weight in green peas.

\begin{tabular}{|c|c|c|c|c|c|c|}
\hline \multirow{2}{*}{$\begin{array}{c}\text { Blanching } \\
\text { treatment } \\
\text { time }\end{array}$} & \multicolumn{3}{|c|}{ After blanching } & \multicolumn{2}{|c|}{$\begin{array}{c}\text { Storage period often } 3 \\
\text { months }\end{array}$} & \multirow[b]{2}{*}{$\%$} \\
\hline & $\begin{array}{l}\text { Zero } \\
\text { time }\end{array}$ & $\begin{array}{c}\text { Change } \\
\text { loss }\end{array}$ & $\%$ & Weighting & $\begin{array}{c}\text { Change } \\
\text { loss }\end{array}$ & \\
\hline 2 minutes & 2.71 & -0.14 & -5.01 & 2.70 & -0.01 & -0.33 \\
\hline 3 minutes & 2.50 & -0.35 & -12.32 & 2.48 & -0.02 & -0.77 \\
\hline 5 minutes & 2.31 & -0.54 & -18.90 & 2.25 & -0.06 & -2.09 \\
\hline
\end{tabular}

The carotenoids in the fresh sample $=2.85 \mathrm{mg} / 100 \mathrm{gm}$.

Table (3-b) record the results of : the effect of blanching treatment times and frozen storage on carotenoids content as percentage of the fresh weight in okra. It records that the loss was slightly for 2 minutes as blanching time $(0.02 \%$ of the fresh sample) . After the frozen storage period the loss for 2 and 5 minutes is (3.05 and 3.04\%) respectively. Our results after blanching for 2 minutes are at the contrast of Abasi et al (1998) while are in agreement with them after the freezing period for 3 and 5 minutes.

Table (3-b) : Effect of blanching treatment times, and frozen storage period at $\left(-20^{\circ} \mathrm{c} \pm 2^{\circ} \mathrm{c}\right)$ on carotenoids content as percentage of fresh weight in okra.

\begin{tabular}{|c|c|c|c|c|c|c|}
\hline \multirow{3}{*}{$\begin{array}{c}\text { Blanching } \\
\text { treatment } \\
\text { time }\end{array}$} & \multicolumn{3}{|c|}{ After blanching } & \multicolumn{3}{|c|}{$\begin{array}{c}\text { Storage period after } 3 \\
\text { months }\left(-20^{\circ} \mathrm{c} \pm 2^{\circ} \mathrm{c}\right)\end{array}$} \\
\hline & \multirow{2}{*}{ Zero time } & \multicolumn{2}{|c|}{ Change loss } & \multirow{2}{*}{$\begin{array}{l}\text { Weight } \\
\text { (mg.) }\end{array}$} & \multicolumn{2}{|c|}{ Change loss } \\
\hline & & (mg.) & $\%$ & & (mg.) & $\%$ \\
\hline 2 minutes. & 3.194 & 0.0006 & -0.02 & 3.25 & 0.07 & -2.06 \\
\hline 3 minutes & 3.06 & 0.26 & -7.91 & 2.96 & -0.10 & -3.05 \\
\hline 5 minutes & 2.92 & 0.40 & -11.98 & 2.82 & 0.10 & -3.04 \\
\hline
\end{tabular}

Carotenoids in the fresh sample $=3.32 \mathrm{mg} / 100 \mathrm{gm}$. 
Table (3-c) represents the effect of blanching treatment times and frozen storage period on the carotenoids content as percentage of the fresh sample in carrots. it represents that blanching for 2 minutes scores the lowest in carotenoids $(1.83 \mathrm{mg})$ than those for 3 or 5 minutes $(4.14$ $\mathrm{mg}$ and $5.7 \mathrm{mg}$ ). As well as after the frozen storage period it scores $1.00,4.54$, and $5.64 \mathrm{mg}$ for 2,3 and 5 minutes respectively. This means that the carotenoids content in the frozen carrots blanched for 2 minutes at zero time or/ and after 3 months (the frozen storage period) at $20^{\circ} \mathrm{c} \pm 2 \mathrm{o}^{\mathrm{C}}$ nearly have no loss more than the fresh sample content. Our results are agreed well with those of Sujala (2001), who freezed carrots, red beat and green peas using sodium metabisulphite amonium bicarbonate and water $\left(90^{\circ} \mathrm{c}\right)$ as blanching treatments for 2,4 and 9 minutes and stored for 3 , 6,9 and 12 months at $-18^{\circ} \mathrm{c}$ they fount that the less loss in carotenoids, content was by using amonium bicarbonate and water $\left(90^{\circ} \mathrm{c}\right)$ blanching treatments for 2 minutes up to 3 months storage.

Table (3-C) : Effect of blanching treatment times, and frozen storage period at $\left(-20^{\circ} \mathrm{c} \pm 2^{\circ} \mathrm{c}\right)$ on carotenoids content as percentage of the fresh sample in carrots.

\begin{tabular}{|c|c|c|c|c|c|c|}
\hline \multirow{3}{*}{$\begin{array}{c}\text { Blanching treatment } \\
\text { time }\end{array}$} & \multicolumn{3}{|c|}{ After blanching } & \multicolumn{3}{|c|}{$\begin{array}{l}\text { Storage period after } 3 \\
\text { months }\left(-20^{\circ} \mathrm{c} \pm 2^{\circ} \mathrm{c}\right)\end{array}$} \\
\hline & \multirow{2}{*}{$\begin{array}{l}\text { Zero } \\
\text { time }\end{array}$} & \multicolumn{2}{|c|}{ Change loss } & \multirow{2}{*}{$\begin{array}{c}\text { Weight } \\
\text { (mg.) }\end{array}$} & \multicolumn{2}{|c|}{ Change loss } \\
\hline & & (mg.) & $\%$ & & (mg.) & $\%$ \\
\hline 2 minutes. & 25.02 & 1.83 & 6.83 & 25.85 & 1.00 & 3.72 \\
\hline 3 minutes & 22.71 & 4.14 & 15.41 & 22.31 & 4.54 & 16.92 \\
\hline 5 minutes & 21.78 & 5.07 & 18.89 & 21.21 & 5.64 & 21.01 \\
\hline
\end{tabular}

Carotenoids in the fresh sample $=26.85 \mathrm{mg} / 100 \mathrm{gm}$. 

vegetables "frozen \& storage at home"

\section{(4) Total sugar content :}

Table (4-a) shows; the effect of blanching treatment times and frozen storage on the total sugar content as percentage of the fresh weight in green peas. The loss of total sugar increased by time increasing and the loss is ($8.01,-9.92$ and $-10.14^{\circ} \%$ of the fresh sample) for 2,3 and 5 minutes respectively after the frozen storage period (3 months); the loss in total sugar for 3 and 5 minutes as blanching time may be the same. $\left(-2.04\right.$ and $2.34^{\circ} \%$ of the fresh weight ) for 3 and 5 minutes respectively. Our results are agreed well with those of Abasi et al., 1998 who stored some frozen vegetables blanched by different media for 3 , 6 and 9 months. They found that water blanching for 2 minutes and stored for 3 months have the less loss in total sugar.

Table (4-a): Effect of blanching treatment times, and frozen storage period on total sugar $\%$ in green peas.

\begin{tabular}{|c|c|c|c|c|c|c|}
\hline \multirow{3}{*}{$\begin{array}{l}\text { Blanching } \\
\text { treatment time }\end{array}$} & \multicolumn{3}{|c|}{ After blanching } & \multicolumn{3}{|c|}{$\begin{array}{l}\text { Storage period after } 3 \\
\text { months }\left(-20^{\circ} c \pm 2^{\circ} \mathrm{c}\right)\end{array}$} \\
\hline & \multirow{2}{*}{$\begin{array}{l}\text { Zero } \\
\text { time }\end{array}$} & \multicolumn{2}{|c|}{ Change loss } & \multirow{2}{*}{$\begin{array}{c}\text { Weight } \\
\text { (mg.) }\end{array}$} & \multicolumn{2}{|c|}{ Change loss } \\
\hline & & (mg.) & $\%$ & & (mg.) & $\%$ \\
\hline 2 minutes. & 25.12 & -2.19 & -8.01 & 26.79 & -0.52 & -1.89 \\
\hline 3 minutes & 24.68 & -2.63 & -9.62 & 26.75 & -0.56 & -2.04 \\
\hline 5 minutes & 24.54 & -2.77 & -10.14 & 26.67 & -0.64 & -2.34 \\
\hline
\end{tabular}

Total sugar in the fresh sample $=27.31 \mathrm{mg} / 100 \mathrm{gm}$.

Table (4-b) indicates the results of the effect of blanching treatment times and frozen storage period on total sugar content as percentage of the fresh weight in okra. It represents that 2 minutes as blanching treatment time scores the less loss percentage in total sugar. Our results are agreed well with those of , Wobdesl (1998) who stored 
okra, broccoli and spinach for 3,6 and 12 months. They found that the best results are for blanched vegetables for 2 minutes and stored for 3 months and not more.

Table (4-b) : Effect of blanching treatment times, and frozen storage period at $\left(-20^{\circ} \mathrm{c} \pm 2^{\circ} \mathrm{c}\right)$ on total sugar content as percentage of the fresh weight in carrots.

\begin{tabular}{|c|c|c|c|c|c|c|}
\hline \multirow{3}{*}{$\begin{array}{c}\text { Blanching } \\
\text { treatment } \\
\text { time }\end{array}$} & \multicolumn{3}{|c|}{ After blanching } & \multicolumn{3}{|c|}{$\begin{array}{l}\text { Storage period after } 3 \text { months } \\
\left(-20^{\circ} \mathrm{c} \pm 2^{\circ} \mathrm{c}\right)\end{array}$} \\
\hline & \multirow{2}{*}{$\begin{array}{c}\text { Zero } \\
\text { time }\end{array}$} & \multicolumn{2}{|c|}{ Change loss } & \multirow{2}{*}{$\begin{array}{c}\text { Weight } \\
\text { (mg.) }\end{array}$} & \multicolumn{2}{|c|}{ Change loss } \\
\hline & & (mg.) & $\%$ & & (mg.) & $\%$ \\
\hline 2 minutes. & 14.01 & -1.20 & -7.90 & 13.51 & -0.50 & -3.32 \\
\hline 3 minutes & 13.39 & -1.82 & -11.95 & 12.91 & -0.48 & -3.17 \\
\hline 5 minutes & 12.93 & 2.28 & -14.98 & 12.45 & -0.48 & -3.14 \\
\hline
\end{tabular}

Total sugar in the fresh sample $=15.21 \mathrm{mg} / 100 \mathrm{gm}$.

The effect of blanching treatment times and frozen storage period on total sugar content as percentage of the fresh weight in carrots are represented in table (4-c). As we mentioned, the total sugar loss increased by blanching time increament. It is $(19.38,28.98$ and $35.44 \%)$ and $(20.06$, 30.01 and $36.91 \%$ ) of the fresh sample before and after the frozen storage period ( 3 months) for 2,3 and 5 minutes respectively. Our results are in agreement with those of Halpin and Lee (2002); who freezed lima, broccoli and pease, then stored them for $3,6,9$ and 12 months. They found that the loss of total sugar increased by blanching time and storage period increament. 
A study on the Nutrient status and sensory evaluation of some vegetables "frozen \& storage at home"

Table (4-C) : Effect of blanching treatment times, and frozen storage period at $\left(-20^{\circ} \mathrm{c} \pm 2^{\circ} \mathrm{c}\right)$ on total sugar content as percentage of the fresh weight in carrots.

\begin{tabular}{|c|c|c|c|c|c|c|}
\hline \multirow{3}{*}{$\begin{array}{l}\text { Blanching } \\
\text { treatment } \\
\text { time }\end{array}$} & \multicolumn{3}{|c|}{ After blanching } & \multicolumn{3}{|c|}{$\begin{array}{l}\text { Storage period after } 3 \text { months } \\
\qquad\left(-20^{\circ} \mathrm{c} \pm 2^{\circ} \mathrm{c}\right)\end{array}$} \\
\hline & \multirow{2}{*}{$\begin{array}{l}\text { Zero } \\
\text { time }\end{array}$} & \multicolumn{2}{|c|}{ Change } & \multirow{2}{*}{$\begin{array}{c}\text { Weight } \\
\text { (mg.) }\end{array}$} & \multicolumn{2}{|c|}{ Change } \\
\hline & & (mg.) & $\%$ & & (mg.) & $\%$ \\
\hline 2 minutes. & 29.59 & 7.11 & 19.38 & 29.34 & 7.36 & 20.06 \\
\hline 3 minutes & 26.06 & 10.64 & 28.98 & 25.69 & 11.01 & 30.01 \\
\hline 5 minutes & 23.69 & 13.01 & 35.44 & 23.15 & 13.55 & 36.91 \\
\hline
\end{tabular}

The total sugar content in the fresh sample $=36.70 \mathrm{mg} / 100 \mathrm{~g}$.

\section{(5) Minerals content:}

The major minerals content of green peas, okra and carrots fresh and after blanching treatment times are recorded in tables (5-a) (5-b) and (5-c) respectively.

All minerals; iron, calcium, phosphorous, sodium and potassium are decreased after blanching treatment. Sodium scores the most loss in all vegetables followed by potassium and phosphorous for 3 and 5 minutes as blanching times.

Table (5-a) shows the effect of blanching treatment times on some minerals content in green peas (the loss as percentage of the fresh sample). It represents that sodium as we mentioned before scores the loss $(13.9,21.6$ and $54.06 \%$ of the fresh sample) for 2,3 and 5 minutes respectively; while Calcium scores the, loss level $(2.27 \%$ of fresh sample) for 2 minutes and potassium (9.52 and $12.42 \%$ ) for 3 and 5 minutes as blanching time. 
A study on the Nutrient status and sensory evaluation of some vegetables "frozen \& storage at home"

Table (5-a) : Effect of blanching treatment times, on some minerals content in green peas (loss percentage of fresh sample).

\begin{tabular}{|c|c|c|c|c|c|c|c|c|c|c|}
\hline \multirow{2}{*}{$\begin{array}{l}\text { Blanching } \\
\text { treatment }\end{array}$} & \multicolumn{2}{|c|}{ Sodium } & \multicolumn{2}{|c|}{ Potassium } & \multicolumn{2}{|c|}{ Calcium } & \multicolumn{2}{|c|}{ Phosphorous } & \multicolumn{2}{|c|}{ Iron } \\
\hline & $\begin{array}{c}\text { Weight } \\
\text { (mg.) }\end{array}$ & $\begin{array}{c}\text { Loss } \\
\%\end{array}$ & $\begin{array}{c}\text { Weight } \\
\text { (mg.) }\end{array}$ & Loss\% & $\begin{array}{c}\text { Weight } \\
\text { (mg.) }\end{array}$ & $\begin{array}{l}\text { Los } \\
\text { s\% }\end{array}$ & $\begin{array}{c}\text { Weight } \\
\text { (mg.) }\end{array}$ & $\begin{array}{c}\text { Loss } \\
\%\end{array}$ & $\begin{array}{c}\begin{array}{c}\text { Weight } \\
\text { (mg.) }\end{array} \\
\text { (m) }\end{array}$ & $\begin{array}{c}\text { Loss } \\
\%\end{array}$ \\
\hline 2 minutes & $\begin{array}{c}0.003 \\
2 \\
\end{array}$ & 13.9 & 1.27 & 0.88 & 0.08 & $\begin{array}{c}2.2 \\
7 \\
\end{array}$ & 0.478 & 0.42 & 0.0081 & 1.25 \\
\hline 3 minutes & $\begin{array}{c}0.002 \\
9\end{array}$ & 21.6 & 1.16 & 9.52 & 0.08 & $\begin{array}{c}1.1 \\
4\end{array}$ & 0.451 & 6.11 & 0.0078 & 5.0 \\
\hline 5 minutes & $\begin{array}{c}0.001 \\
7\end{array}$ & 54.06 & 1.12 & 12.42 & 0.08 & $\begin{array}{c}1.1 \\
4\end{array}$ & 0.433 & 9.83 & 0.0077 & 7.7 \\
\hline $\begin{array}{c}\text { Fresh } \\
\text { sample (mg.) }\end{array}$ & \multicolumn{2}{|c|}{0.0037} & \multicolumn{2}{|c|}{1.280} & \multicolumn{2}{|c|}{0.082} & \multicolumn{2}{|c|}{0.480} & \multicolumn{2}{|c|}{0.0083} \\
\hline
\end{tabular}

Table (5-b) shows the effect of blanching treatment times on some minerals content in okra (the loss as percentage of the fresh sample) it clears that as we mentioned before; sodium scores the lowest loss (14.1, 14.77 and $17.45 \%$ of the fresh sample) for 2.3 and 5 minutes as blanching treatment times. calcium scores the second loss level $(2.47 \%$ of the fresh sample) for 2 minutes Potassium scores the second loss level (12.27 and 14.08\%) for 3 and 5 minutes as blanching treatment times.

Table (5-b) : Effect of blanching treatment times, on some minerals content in okra (loss percentage of the fresh sample)

\begin{tabular}{|c|c|c|c|c|c|c|c|c|c|c|}
\hline \multirow{2}{*}{$\begin{array}{l}\text { Blanching } \\
\text { treatment }\end{array}$} & \multicolumn{2}{|c|}{ Sodium } & \multicolumn{2}{|c|}{ Potassium } & \multicolumn{2}{|c|}{ Calcium } & \multicolumn{2}{|c|}{ Phosphorous } & \multicolumn{2}{|c|}{ Iron } \\
\hline & $\begin{array}{c}\text { Weight } \\
\text { (mg.) }\end{array}$ & Loss \% & $\begin{array}{c}\text { Weight } \\
\text { (mg.) }\end{array}$ & Loss \% & $\begin{array}{c}\text { Weight } \\
\text { (mg.) }\end{array}$ & $\begin{array}{c}\text { Loss } \\
\%\end{array}$ & $\begin{array}{l}\text { Weight } \\
\text { (mg.) }\end{array}$ & $\begin{array}{c}\text { Loss } \\
\%\end{array}$ & $\begin{array}{l}\text { Weight } \\
\text { (mg.) }\end{array}$ & $\begin{array}{c}\text { Loss } \\
\%\end{array}$ \\
\hline 2 minutes & 1.28 & 14.10 & 2.74 & 0.91 & 2.76 & 2.47 & 4.71 & 0.44 & 0.89 & 1.11 \\
\hline 3 minutes & 1.27 & 14.77 & 2.43 & 12.27 & 2.76 & 2.47 & 4.67 & 1.27 & 0.89 & 1.11 \\
\hline 5 minutes & 1.23 & 17.45 & 2.38 & 14.08 & 2.75 & 2.83 & 4.58 & 3.17 & 0.89 & 1.11 \\
\hline $\begin{array}{c}\text { Fresh sample } \\
(\mathrm{mg} .)\end{array}$ & \multicolumn{2}{|c|}{1.49} & \multicolumn{2}{|c|}{2.77} & \multicolumn{2}{|c|}{2.83} & \multicolumn{2}{|c|}{4.73} & \multicolumn{2}{|c|}{0.90} \\
\hline
\end{tabular}

Table (5-c) clears the results of the effect of blanching treatment times on some minerals in carrots. sodium. It scores the lowest loss 11.07, 14.71 and $17.42 \%$ 
of the fresh sample for 2, 3 and 5 minutes as blanching treatment times respectively, meanwhile phosphorous and potassium show $(10.45,13.19 \%)$ and $10.03,12.89$ of fresh sample) for 3 and 5 minutes respectively. Our results are agreed well with those of Sujala (2001).

Table (5-C):Effect of blanching treatment times, on some minerals content in carrots (loss in percentage of the fresh sample)

\begin{tabular}{|l|c|c|c|c|c|c|c|c|c|c|}
\hline $\begin{array}{c}\text { Blanching } \\
\text { treatment } \\
\text { times }\end{array}$ & \multicolumn{2}{|c|}{ Sodium } & \multicolumn{2}{c|}{ Potassium } & \multicolumn{2}{c|}{ Calcium } & \multicolumn{2}{|c|}{ Phosphorous } & \multicolumn{2}{c|}{ Iron } \\
\cline { 2 - 12 } & $\begin{array}{c}\text { Weight } \\
\text { (mg.) }\end{array}$ & Loss & $\begin{array}{c}\text { Weight } \\
\text { (mg.) }\end{array}$ & $\begin{array}{c}\text { Loss } \\
\text { \% }\end{array}$ & $\begin{array}{c}\text { Weight } \\
\text { (mg.) }\end{array}$ & $\begin{array}{c}\text { Loss } \\
\text { \% }\end{array}$ & $\begin{array}{c}\text { Weight } \\
\text { (mg.) }\end{array}$ & $\begin{array}{c}\text { Loss } \\
\%\end{array}$ & $\begin{array}{c}\text { Weight } \\
\text { (mg.) }\end{array}$ & $\begin{array}{c}\text { Loss } \\
\%\end{array}$ \\
\hline 2 minutes & 372.51 & 11.07 & 2679.8 & 0.75 & 328.0 & 3.80 & 283.9 & 2.45 & 6.98 & 0.29 \\
\hline 3 minutes & 358.21 & 14.71 & 2429.2 & 10.03 & 319.8 & 6.22 & 260.6 & 10.45 & 6.97 & 0.43 \\
\hline 5 minutes & 346.83 & 17.42 & 2352 & 12.89 & 317.9 & 6.77 & 252.62 & 13.19 & 6.94 & 0.86 \\
\hline $\begin{array}{l}\text { In fresh } \\
\text { sample }\end{array}$ & \multicolumn{2}{|c|}{420} & \multicolumn{2}{|c|}{2700} & \multicolumn{2}{|c|}{341} & & 291 & & 7.00 \\
\hline
\end{tabular}

\section{Sensory evaluation:}

\section{Green peas :}

\section{Color :}

Table (6-a) shows the effect of blanching treatment times on organoleptic evaluation of green peas. It is clear that color difference and chroma are improved significantly at $p \leq 0.05$. The panel taste members have no differences.

Fracis (1995) studied the correlation between the ratio of column stimulus values and the visual color of green peas. They reported that color became more green when treated by water at $90^{\circ} \mathrm{c}$ for 2 minutes or treated by steam for 3 minutes. They reported also that storage frozen green peas for 12 months at $-20^{\circ} \mathrm{c}$ tended to lighten colour. They reported also that the specific colour differences were not noted by taste panel members. Our results are in agreement with those of Fracis (1995). 
A study on the Nutrient status and sensory evaluation of some vegetables "frozen \& storage at home"

Table (6-a): Effect of blanching treatment times, on organoleptic evaluation of green peas.

\begin{tabular}{|c|c|c|c|}
\hline Blanching treatment times & Color Difference & $\underline{\text { Chroma }}$ & Hue \\
\hline Fresh sample (Water at 9o $\left.\mathbf{~}^{\mathbf{0}} \mathbf{c}\right)$ & 61.79 & 12.37 & 2.85 \\
\hline 2 minutes & 63.03 & 14.52 & 1.66 \\
\hline 3 minutes & 68.89 & 14.55 & 1.50 \\
\hline 5 minutes & 68.07 & 14.63 & 1.89 \\
\hline
\end{tabular}

The panel test members record no differences.

\section{Flavour :}

Table (7-a) shows the effect of frozen storage on organoleptic evaluation of green pease after 3 months storage at $-20^{\circ} \mathrm{c} \pm 2^{\circ} \mathrm{c}$. It is clear that color and texture differences are significant at $\mathrm{p} \leq 0.05$; while flavour differences score no significant. Our results are agreed well with those of Aparicio et al., (1999) who studied the effect of frozen storage at $-23^{\circ} \mathrm{c}$ for 12 months on the normal flavor of green beans (corresponded to the fresh sample. They could not fined any significant differences.

The panel taste members have no differences. Our results are agreed well with those of Fracis (1995) as we mentioned before.

\section{Texture :}

Our results in table (7-a) as we mentioned before texture is less firmness. It is agreed well with those of Odland and Eheart (1998). They studied the effect of water and steam on texture of the frozen broccoh (as blanching treatment media). They found that the texture of steam blanched broccoli was preferred over that of water blanching. Also They found that broccoli was more sloughed and less firm than steam - blanched one. The differences were not significant. Our results are at the 
A study on the Nutrient status and sensory evaluation of some vegetables "frozen \& storage at home"

opposite of them. Our results have significant differences within Column. The panel taste members have no differences as it is shown in table (7-a)

Table (7-a) : Effect of frozen storage on organoleptic evaluation of green peas after 3 months of storage.

\begin{tabular}{|c|c|c|c|}
\hline $\begin{array}{c}\text { Blanching treatment } \\
\text { (water at } 90^{\mathbf{0}} \mathbf{c} \text { ) }\end{array}$ & Color & Flavor & Texture \\
\cline { 2 - 4 } & Mean \pm S.D & Mean \pm S.D & $\begin{array}{c}\text { Mean } \pm \\
\text { S.D }\end{array}$ \\
\hline 2 minutes & $7.4 \pm 0.69^{\mathrm{bc}}$ & $6.9 \pm 0.77$ & $7.7 \pm 0.70^{\mathrm{ab}}$ \\
\hline 3 minutes & $7.0 \pm 0.69^{\mathrm{c}}$ & $7.0 \pm 0.84$ & $7.6 \pm 0.8 .3^{\mathrm{ab}}$ \\
\hline 5 minutes & $7.0 \pm 0.69^{\mathrm{c}}$ & $7.0 \pm 0.69$ & $7.5 \pm 0.63^{\mathrm{ab}}$ \\
\hline
\end{tabular}

The taste panel members have no differences.

a-c: means within column with different superscript are Significant at $(P \leq 0.05)$.

\section{Okra :}

Table (6-b) represents the scores of the effect of blanching treatment on organoleptic evaluation of okra. It is clear that color and texture scores were decreasing slightly with blanching time increasing; while flavour scores were increasing slightly. All the results are non significant.

Table (6-b) : Effect of blanching treatment times on the organoleptic evaluation of okra

\begin{tabular}{|l|c|c|c|}
\hline \multicolumn{1}{|c|}{$\begin{array}{c}\text { Blanching treatment } \\
\text { times }\end{array}$} & Color & Flavor & Texture \\
\cline { 2 - 4 } & Mean \pm S.D & Mean \pm S.D & Mean \pm S.D \\
\hline 2 minutes & $6.3 \pm 0.81^{*}$ & $6.8 \pm 0.91$ & $7.2 \pm 0.63$ \\
\hline 3 minutes & $6.3 \pm 0.98^{*}$ & $6.9 \pm 0.69$ & $6.8 \pm 0.61$ \\
\hline 5 minutes & $5.69 \pm 1.09$ & $7.0 \pm 0.95$ & $6.89 \pm 0.73$ \\
\hline
\end{tabular}

The panelist record that their is no differences

* significance level $\mathbf{P} \leq \mathbf{0 . 0 5}$

The effect of frozen storage on organoleptic evaluation of okra after three months of storage at $-20 \mathrm{c} \pm$ $2^{\circ} \mathrm{c}$ are shown in table (7-b). it is clean that color and texture scores decreased slightly with time increasing. Flavour increased slightly. The taste panel members noted that there is no differences. Our results are inagreement with 
A study on the Nutrient status and sensory evaluation of some vegetables "frozen \& storage at home"

those of Fracis (1995) "as we mentioned before".

Table (7-b) : Effect of frozen storage on organoleptic evaluation of okra after 3 months $\left(-20^{\circ} \mathrm{c} \pm 2^{\circ}\right)$

\begin{tabular}{|c|c|c|c|}
\hline \multirow{2}{*}{$\begin{array}{c}\text { Blanching } \\
\text { treatment times }\end{array}$} & Color & Flavor & Texture \\
\cline { 2 - 4 } & Mean \pm S.D & Mean \pm S.D & Mean \pm S.D \\
\hline 2 minutes & $5.83 \pm 0.88^{*}$ & $5.9 \pm 0.77$ & $6.3 \pm 0.6 .4$ \\
\hline 3 minutes & $5.6 \pm 0.92^{*}$ & $5.9 \pm 0.77$ & $6.2 \pm 0.64$ \\
\hline 5 minutes & $5.4 \pm 0.69$ & $6.0 \pm 0.48$ & $6.15 \pm 0.76$ \\
\hline
\end{tabular}

The taste panel members noted, that there is no differences.

* Significant at $(\mathbf{P} \leq \mathbf{0 . 0 5})$.

\section{Carrots :}

Table (6-c) shows the effect of blanching time on organoleptic evaluation of carrots. It clears that the scores of colour and texture are decreased slightly with blanching time increament. All differences are significant at $p \leq 0.05$.

Table (6-C): Effect of blanching treatment times on organoleptic evaluation of carrots

\begin{tabular}{|c|c|c|c|}
\hline Blanching treatment & Color & Flavor & Texture \\
\cline { 2 - 4 } times & Mean \pm S.D & Mean \pm S.D & Mean \pm S.D \\
\hline 2 minutes & $7.94 \pm 0.83$ & $6.55 \pm 0.66$ & $7.45 \pm 1.00$ \\
\hline 3 minutes & $7.49 \pm 0.86$ & $7.16 \pm 0.88$ & $7.31 \pm 6.6$ \\
\hline 5 minutes & $7.36 \pm 0.66$ & $7.18 \pm 0.62$ & $6.78 \pm 0.43$ \\
\hline
\end{tabular}

- Means within column with different superscripts are significant at $\mathrm{P} \leq 0.05$

The results of the effect of frozen storage period on organoleptic evaluation of carrots are shown in table (7-c). color scores decreased slightly and texture has the same trend; while flavor scores increased slightly too with blanching time increment. All the results are significant at $p \leq 0.05$. the taste panel members have no differences. 
A study on the Nutrient status and sensory evaluation of some vegetables "frozen \& storage at home"

Table (7-C) : Effect of freezing storage. on organoleptic evaluation of carrots after 3 months at $-20^{\circ} \mathrm{c} \pm 2^{\circ} \mathrm{c}$.

\begin{tabular}{|c|c|c|c|}
\hline Blanching & Color & Flavor & Texture \\
\cline { 2 - 4 } treatment times & Mean \pm S.D & Mean \pm S.D & Mean \pm S.D \\
\hline 2 minutes & $7.51 \pm 0.69^{*}$ & $6.79 \pm 0.78$ & $6.59 \pm 0.82^{*}$ \\
\hline 3 minutes & $7.42 \pm 0.96^{*}$ & $6.88 \pm 0.77$ & $6.50 \pm 0.70^{*}$ \\
\hline 5 minutes & $6.8 \pm 0.63^{*}$ & $7.01 \pm 0.67$ & $6.50 \pm 0.55^{*}$ \\
\hline
\end{tabular}

Means within column with different superscripts are *significant at $(\mathrm{P} \leq \mathbf{0 . 0 5})$

\section{After cooking :}

The taste panel members record no differences in flavor, color or texture. The nutritional value can be improved by adding meat, onion, tomato... etc as well as flavor can be improved by adding spices and salt as it is behave for cooking. Lion, 1999 refered that ; significant differences in color and texture were detected by objective measurements.

\section{REFFERENCES}

1- Abasi, B.H; Bennet, Mel and stepwise, W.A. (1998). Effect of freezing, frozen storage on the quality of vegetables.J. food science.Dec. Vol. 40 pp: 1175 : 91.

2- A.O.A.C ( 1985): Official methods analysis chemistries $13^{\text {th }}$ ed.,Association of official analytical chemists. Washington, Dc.USA. Pp: 131: 215.

3- Aparicio, G .; Ganzolo, J.C. and Meta, N. (1999): Sensory evaluations and changes in peroxidase activity during storage of frozen green beans. J., food science, Vol. 57. Pp 1129 - 1131.

4- EIKner, JH ., Ahola , IE ; Sarkinen, E. and Kern, P. (1998): Effect of frozen storage on the nutrients status of carrots and peas. Research institue of vegetables 
(rops. Buletin, 49 . pp. 107-120).

5- Fracis, FJ - (1995): Food colorimetry : Theory and applications. The Avi publishing co., Inc., westport, conn, USA. pp; 1197 : 1205.

6- Gasilva , R.L. Hopel , E.R and River , R. A. ( 2001) : Effect of soaking blanching conditions on glucose losses in potato slices. Can ., int, Je food Sci ., $17: 112$.

7- Halpin , B.E. and Lee , c - y - (2002) : Effect of blanching on enzyme activity and quality changes in green peas. J. food sci ., pp. $060-1150$.

8- Hiak , D. L . ( 1998) : Effect of internal and oven tempratures on eating quality of light and dark meat . food technology. pp. $21: 90$.

9- Harris, L. D ( 1998) : Enzymes in food processing, 2 nd ed ., Academic press . USA, UK . pp : $116: 120-$ $290: 298$.

10- jacob , Ml . (1958) : Soil chemical analysis . contable co., London. England - pp : 444: 498.

11- Katsaboxakis , K. Z . (2000) : The influence of the degree of blanching on the quality of frozen vegetables . A lecture in : thermal processing and quality of food. FSTA. Pp 21.

12- Lion . B . 1999 : Experimental cookers. Wiley and Sono., India , New York . pp . $225-235$.

13- Mitchell. L . ( 1999) : Blanching of green peas physical and organoleptic assessment of the efficiency of water blanching. food technology no ., 23 pp $104-107$.

14- Monzini, A. :Thomas, D. and Bracy, D. (1999): Structural modifications in frozen vegetables. 
CAB Abstracts Database Dialog information service, Inc ., pp $239-205$.

15- Odland , D . and Eheart , M . ( 1998) : The freezing preservation of fruits, fruit juices and vegetables . J . food sci 957 . pp : $1129: 1131$.

16- Polo , M . ( 1999 ) : Stepwise blanching and its importance in freezing of vegetables. In ; Refregeration in the service of man. XVI the international congress of refregeration. Paris . pp : $631-633$.

17-Shibairo, S.; Ward, J. and Lee, J. (2001) : Post freezing storage moisture loss charactaristics of green peas (during short-term storage). Journal of plant science, vol ., b No ., $71-\mathrm{pp}:$ 1-12.

18- Smogyi,M.( 1945) : Notes on sugar determination . J . Biol ., pp : $160-195$.

19- Sujala . T . ( 2001) : Some factors affecting rates of heat inactivation and reactivation of horseradish peroxidase. J. food sci , 39. Pp : $1154: 1173$.

20- Wetlestein , DV . ( 1957) : Carotenoids and chlorophyll determination and submicroskopische for plastiden experimental cell research. pp : $412: 427$.

21- Wobdesl , R . ( 1998) : Effect of blanching treatments and marketing storage on the frozen vegetables food science No ., 31 . pp $169: 182$.

22- Wongana, S., (1987): Manual of analysis of fruit \& vegetable products. Tata Mc. Graw-Hill publighing Co., Ltd., New York. 